\title{
Corrigendum: Biosecurity policy in the US: a critical assessment
}

\author{
Ori Lev ${ }^{1 *}$ and Limor Samimian-Darash ${ }^{2}$ \\ ${ }^{1}$ Department of Public Policy and Administration and Masters Program in Public Policy, Sapir College, D.N. Hof Ashkelon, \\ Israel, ${ }^{2}$ The Federmann School of Public Policy and Government, The Hebrew University of Jerusalem, Jerusalem, Israel
}

Keywords: dual use research of concern, risk-benefit assessment, biosecurity policy, H5N1, US Government Policy

\section{A corrigendum on}

Biosecurity policy in the US: a critical assessment

by Lev O, Samimian-Darash L. Front Public Health (2014) 2:110. doi: 10.3389/fpubh.2014.00110

The authors would like to add the following correction to the Opinion article to now include the acknowledgment of funding for their research.

\section{FUNDING}

Financial support for this research provided by The Israeli Ministry of Science, Technology, and Space. Grant no. 3-10739.

OPEN ACCESS

Edited by:

John W. Rossen,

University of Groningen, Netherlands

Reviewed by:

Kai Zhou,

University Medical Center Groningen,

Netherlands

Ruud H. Deurenberg,

University Medical Center Groningen,

Netherlands

${ }^{*}$ Correspondence:

Ori Lev

orilev22@gmail.com

Specialty section:

This article was submitted to

Infectious Diseases, a section of the

journal Frontiers in Public Health

Received: 13 October 2015

Accepted: 19 October 2015

Published: 03 November 2015

Citation:

Lev O and Samimian-Darash L (2015) Corrigendum: Biosecurity policy in the

US: a critical assessment.

Front. Public Health 3:247.

doi: 10.3389/fpubh.2015.00247
Conflict of Interest Statement: The authors declare that the research was conducted in the absence of any commercial or financial relationships that could be construed as a potential conflict of interest.

Copyright $(2015$ Lev and Samimian-Darash. This is an open-access article distributed under the terms of the Creative Commons Attribution License (CC BY). The use, distribution or reproduction in other forums is permitted, provided the original author(s) or licensor are credited and that the original publication in this journal is cited, in accordance with accepted academic practice. No use, distribution or reproduction is permitted which does not comply with these terms. 